\title{
Bioethanol fermentation from kitchen waste using
}

\section{Saccharomyces cerevisiae [version 1; peer review: 2 not}

\section{approved]}

\section{Shafkat Shamim Rahman (D1,2, Md. Mahboob Hossain1, Naiyyum Choudhury1,3}

${ }^{1}$ Department of Mathematics and Natural Sciences, BRAC University, Dhaka, 1212, Bangladesh

2United Surgical Ltd., Gazipur, 1702, Bangladesh

${ }^{3}$ Bangladesh Atomic Energy Regulatory Authority, Dhaka, 1207, Bangladesh

\author{
V1 First published: 27 Apr 2018, 7:512 \\ https://doi.org/10.12688/f1000research.14594.1 \\ Latest published: 27 Apr 2018, 7:512 \\ https://doi.org/10.12688/f1000research.14594.1
}

\section{Abstract}

Bioethanol obtained from microbial fermentation can replace conventional fossil fuels to satisfy energy demand. In this respect, a fermenting isolate of Saccharomyces cerevisiae, obtained from date juice, was grown in YEPD medium as a part of a previous published research project. In this study, the isolate was tentatively characterized for alcoholic fermentation in organic kitchen waste medium, prepared from discarded fruit and vegetable peels.

Fermentation in shaking condition resulted in the production of $7.3 \%$ $(\mathrm{v} / \mathrm{v})$ ethanol after $48 \mathrm{~h}$, after which the $\mathrm{pH}$ of the medium increased slightly in response. Further research should be conducted to assess the potential of kitchen waste as a raw material in ethanol fermentation.

\section{Keywords}

Kitchen waste; Saccharomyces cerevisiae; Fermentation; Bioethanol

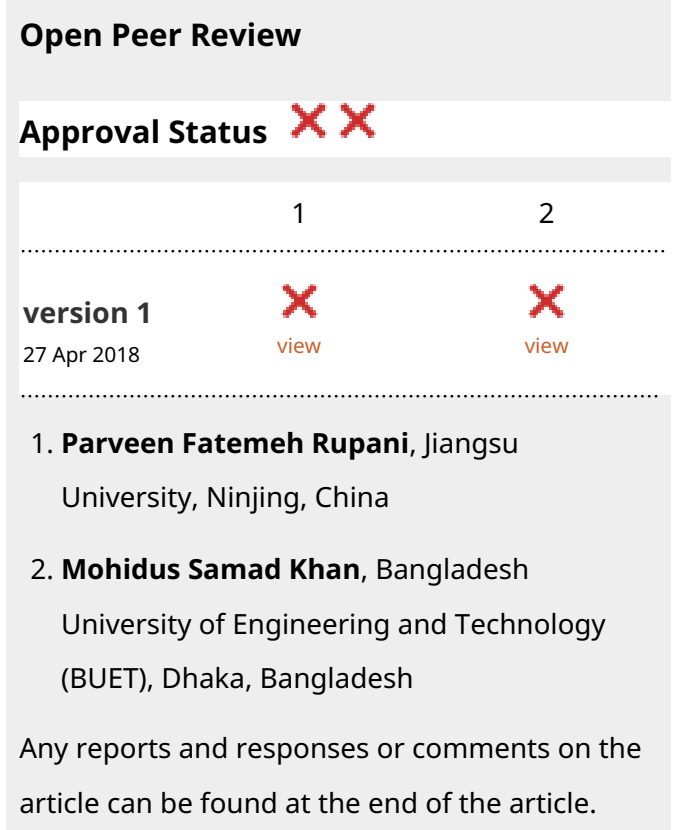

Corresponding author: Shafkat Shamim Rahman (shafkatshamimrahman@gmail.com)

Author roles: Rahman SS: Data Curation, Formal Analysis, Investigation, Validation, Visualization, Writing - Original Draft Preparation, Writing - Review \& Editing; Hossain MM: Conceptualization, Methodology, Project Administration, Resources, Supervision, Validation; Choudhury N: Conceptualization, Methodology, Project Administration, Resources, Supervision, Validation

Competing interests: No competing interests were disclosed.

Grant information: The author(s) declared that no grants were involved in supporting this work.

Copyright: @ 2018 Rahman SS et al. This is an open access article distributed under the terms of the Creative Commons Attribution License, which permits unrestricted use, distribution, and reproduction in any medium, provided the original work is properly cited.

How to cite this article: Rahman SS, Hossain MM and Choudhury N. Bioethanol fermentation from kitchen waste using Saccharomyces cerevisiae [version 1; peer review: 2 not approved] F1000Research 2018, 7:512 https://doi.org/10.12688/f1000research.14594.1

First published: 27 Apr 2018, 7:512 https://doi.org/10.12688/f1000research.14594.1 


\section{Introduction}

Kitchen waste is a raw material available in large volumes. The term applies to organic solids, which are discarded during food preparation. Kitchen waste is mostly composed of lignocelluloses and starch, and is degradable through microbial infestation. An outstanding resource for biotechnology is present in kitchen waste as carbohydrate polymer fraction ${ }^{1}$. The usage of lignocelluloses as feedstock would prompt novel challenges for biotechnology, for example, the product diversification ${ }^{2,3}$.

Kitchen waste extracted bioethanol is an alluring and sustainable energy source for vehicle fuel, as a gasoline alternative. Present ethanol production (so-called 'first generation'), utilizing harvests such as sugar cane and corn, has become conventional method, whereas second-generation ethanol generation uses less expensive, non-sustenance feedstocks, for example, lignocelluloses or municipal solid waste, which could make ethanol more competitive alternative to petroleum ${ }^{4,5}$.

Plant cell walls are mostly composed of lignocellulosic biomass. Among its main components is cellulose, a linear polymer of cellobiose consisting of two D-glucose molecules connected by $\beta-1,4$ bonds $^{6}$. The more organized or crystalline cellulose is, the less soluble and less degradable it is. Cellulose degradation techniques include the use of effective enzymes, concentrated acid or alkaline and high temperatures for both nebulous and crystalline cellulose in the transformation procedure. Cellulose would be an ideal carbohydrate source for the fermentation due to the uniform hydrolyzable glucose building blocks ${ }^{7}$.

Hemicellulose is another important hetero-polysaccharide present in the plant cell wall. Hemicellulose differs from cellulose by the organization of several sugar units, by the presence of shorter chains and by a ramified central chain. Hemicellulose removal from the plant cell wall is easier than lignin and cellulose, owing to the bonds between cellulose, hemicellulose and lignin. A wide variety of enzymes, including endoxylanase, exoxylanase, mannanase, arabinosidase, acetylesterase, and glucoronisidase, are essential due to its structural diversity ${ }^{8}$. Alkaline pretreatments were also found to be successful at degrading hemicellulose 9 .

Lignin provides additional strength and protection to prevent enzymatic activity of fungi and insect attack by linking cellulose and hemicellulose ${ }^{10}$. Substantial moisture and rigidity resistance also added to biomass ${ }^{11}$ and known as a cellulase inhibitor $^{12}$. As a result, exogenous proteins, such as bovine serum albumin, and surfactants, such as $\mathrm{MgSO}_{4}$, and $\mathrm{CaCl}_{2}{ }_{2}^{13}$, are added before microbial or enzyme loading. Moreover, many pretreatment processes have been established to moderate the lignin hindrance.

Functional groups of lignin, including phenolic hydroxyl, benzyl hydroxyl, methoxyl, carbonyl and a minor amount of terminal aldehyde groups, are factors that influence its decomposition ${ }^{14}$. The lignin carbohydrate complexes (syringyl, guaiacyl and p-hydroxyphenyl units) formed by crosslink interactions, are also counted as a fermentation-restricting factor.

Starch ( $\alpha$-D-glucose monomer) degradation is complex than the sugar fermentation process. It initially broke down into glucose, through amylase or diastase and maltase hydrolysis. Then, ethanol and carbon dioxide are fermented from sugars through enzyme activity.

Alongside a mainstream $\operatorname{project}^{15,16}$, in this study, tentative fermentation was carried out in kitchen waste medium to find out if a wild-type microorganism has the ability to ferment cellulose efficiently ${ }^{17}$.

\section{Methods}

\section{Composition and pretreatment}

Yeast samples (Saccharomyces cerevisiae) were isolated and identified from date-juice using previously described methods ${ }^{15,18}$ in YEPD medium $\left(10^{6}-10^{7}\right.$ cells $/ \mathrm{ml} ; 0.3 \%$ yeast extract \#Y1625, 1\% peptone \#P7750, 2\% dextrose \#G8270, 1.5\% agar \#A1296, pH: 5; Sigma-Aldrich, St Louis, MO, USA). Discarded solid kitchen waste was collected from different households. This included peels from potatoes, pumpkin, papaya, cucumber, okra, green banana, balsan apple, carrot and basil. After chopping, pulverizing and blending with $1 \mathrm{~L}$ water, $250 \mathrm{~g}$ solid waste was taken as raw medium. Concentrated $\mathrm{HCl}(2 \mathrm{ml})$ was added to convert the calcium present (a fermentation inhibitor) to calcium sulfate salt ${ }^{19}$. $\mathrm{HCl}$ also regulates the $\mathrm{pH}$ of the medium to control for bacterial contamination and facilitate chemical hydrolysis of plant residues, which were boiled for $1.5 \mathrm{~h}$, giving carbohydrate units of cellulose and starch. Monomers of amylose, amylopectin and glucose arose from further degradation. Urea $(0.1 \mathrm{~g})$ was also supplemented prior to boiling as a nitrogen source nutrient. The final $\mathrm{pH}$ was adjusted to 6.0 by dropwise addition of $\mathrm{NaOH}$ or $\mathrm{HCl}$ (measured using a $\mathrm{pH}$ meter; Mettler Toledo, Switzerland).

\section{Fermentation}

The $250 \mathrm{ml}$ fermentation medium was transferred into $500 \mathrm{ml}$ Erlenmeyer flasks and a homogenous suspension of yeast (10 ml YEPD broth) was inoculated in aseptic conditions. The flask was incubated in a rotary incubator $(120 \mathrm{rpm})$ at $30^{\circ} \mathrm{C}$ for 48 h. Two separate experiments were conducted and ethanol production was recorded at 24 and $48 \mathrm{~h}$ intervals, and the average were calculated. The ethanol in this experiment was analyzed using the Conway method ${ }^{20}$. Downstream processing is required before isolation of usable ethanol.

\section{Results}

Previous investigations ${ }^{15,16,18}$ indicated that ethanol is produced more readily under shaking than non-shaking conditions. After $48 \mathrm{~h}$ of fermentation at room temperature in a rotary incubator $(120 \mathrm{rpm})$, a maximum of $7.3 \%(\mathrm{v} / \mathrm{v})$ ethanol production was recorded (Table 1). The rate of alcohol production showed a cumulatively increasing trend, which was mirrored by a continued rise in $\mathrm{pH}$ throughout incubation, recorded as $\mathrm{pH} 6.52$ at 


\section{Table 1. pH change and alcohol production after 48 $\mathrm{h}$ fermentation.}

\begin{tabular}{|c|c|c|c|c|c|c|}
\hline \multicolumn{7}{|c|}{ Alcohol production (v/v) } \\
\hline Initial & \multicolumn{3}{|l|}{$24 \mathrm{~h}$} & \multicolumn{3}{|l|}{$48 \mathrm{~h}$} \\
\hline \multirow{2}{*}{0} & 1st & 2nd & Avg. & 1st & 2nd & Avg. \\
\hline & $3.39 \%$ & $3.34 \%$ & $3.37 \%$ & $7.4 \%$ & $7.1 \%$ & $7.3 \%$ \\
\hline \multicolumn{7}{|c|}{ pH change } \\
\hline Initial & \multicolumn{3}{|l|}{$24 \mathrm{~h}$} & \multicolumn{3}{|l|}{$48 \mathrm{~h}$} \\
\hline \multirow{2}{*}{6} & 1st & 2nd & Avg. & 1st & 2nd & Avg. \\
\hline & 6.28 & 6.39 & 6.34 & 6.45 & 6.59 & 6.52 \\
\hline
\end{tabular}

$48 \mathrm{~h}$. The results also indicated that the full potential of kitchen waste fermentation will be revealed through longer durations of fermentation.

\section{Discussion}

The kitchen waste medium contained plant organelles and was a rich source of cellulose, starch and glucose monomers. Comparison with previous studies ${ }^{15,16,18}$ showed the achieved production efficiency is below the level required for profitable commercial production. In this study, production of $7.3 \%(\mathrm{v} / \mathrm{v})$ ethanol was recorded (Table 1). Further optimization of the process and co-fermentation (e.g. ethanol-butanol co-fermentation) is among the future goals of researchers ${ }^{21}$.

Most of the kitchen waste was similar feedstock to lignocellulosic raw materials, which is considered to be an excellent substrate $^{22}$. Previous works delineated the pathway of converting plant-based waste biomass to bioethanol, in which enzyme pretreatment was conducted before yeast fermentation ${ }^{23-26}$. Gnansounou \& Dauriat produced $30.9 \mathrm{~g}$ bioethanol and $65.2 \mathrm{~L}$ biogas using $1 \mathrm{~kg}$ of kitchen waste $^{27}$. Velasquez \& Ruiz fermented 346.5-388.7 1/ton bioethanol in a similar study using banana pulp and $\operatorname{skin}^{28}$. Industrial waste has also been used in fermentation technology ${ }^{29}$. A planned facility in East London will produce 16 million gallons of jet fuel per annum from 500,000 tons of waste for British Airways (the Green Sky project). A combination of plasma arc gasification with the Fischer-Tropsch method, known as Solena's Plasma Gasification (SPG) technology, will be used. In China's Jiangsu province, a new waste-to-energy facility with a processing capacity of 900 metric tons, will be constructed.

\section{Conclusions}

Results were derived from limited parameters and only a single isolate of microorganism was employed. Future studies should be directed towards elaborate characterization and compare different criteria of kitchen waste fermentation. Optimization of the media and physicochemical parameters, and longer-duration fermentation will also be performed in future. This study was aimed towards fermentation only. A cheap, efficacious downstream processing method of the ethanol generated in this process also requires development.

\section{Data availability}

All data underlying the results are available as part of the article and no additional source data are required.

\section{Author information}

When the research was carried out, SSR was a MSc student at Biotechnology program, Department of Mathematics and Natural Sciences, BRAC University and NC was the Coordinator of Biotechnology and Microbiology programmes at the Department of Mathematics and Natural Sciences, BRAC University.

\section{Competing interests}

No competing interests were disclosed.

\section{Grant information}

The author(s) declared that no grants were involved in supporting this work.

\section{Acknowledgements}

Authors are grateful to the late Prof. Dr. AAZ Ahmad, former Chairperson of Department of MNS, BRAC University, Dhaka, for allowing the research work. Their sincere appreciation goes to Armanul Nasir, Arif, Forkan and Shamim Akhter Chowdhury for their graceful help and support.
1. Hossain N, Zaini JH, Mahlia TM: A Review of Bioethanol Production from Plantbased Waste Biomass by Yeast Fermentation. Int J Technol. 2017; 8(1): 5-18. Publisher Full Text

2. Peris D, Moriarty RV, Alexander WG, et al:: Hybridization and adaptive evolution of diverse Saccharomyces species for cellulosic biofuel production. Biotechnol Biofuels. 2017; 10: 78

PubMed Abstract | Publisher Full Text | Free Full Text

3. Jayakody LN, Ferdouse J, Hayashi N, et al:: Identification and detoxification of glycolaldehyde, an unattended bioethanol fermentation inhibitor. Crit Rev Biotechnol. 2017; 37(2): 177-89. PubMed Abstract | Publisher Full Text
4. Lee YG, Jin YS, Cha YL, et al.: Bioethanol production from cellulosic hydrolysates by engineered industrial Saccharomyces cerevisiae. Bioresour Technol. 2017; 228: 355-61. PubMed Abstract | Publisher Full Text

5. Lee CR, Sung BH, Lim KM, et al:: Co-fermentation using Recombinant Saccharomyces cerevisiae Yeast Strains Hyper-secreting Different Cellulases for the Production of Cellulosic Bioethanol. Sci Rep. 2017; 7(1): 4428. PubMed Abstract | Publisher Full Text | Free Full Text

6. Lynd LR, Weimer PJ, van Zyl WH, et al.: Microbial cellulose utilization: fundamentals and biotechnology. Microbiol Mol Biol Rev. 2002; 66(3): 506-577. PubMed Abstract | Publisher Full Text | Free Full Text 
7. Zhang YH, Lynd LR: Toward an aggregated understanding of enzymatic hydrolysis of cellulose: noncomplexed cellulase systems. Biotechnol Bioeng. 2004; 88(7): 797-824.

PubMed Abstract | Publisher Full Text

8. Thygesen A, Thomsen AB, Schmidt AS, et al:: Production of cellulose and hemicellulose-degrading enzymes by filamentous fungi cultivated on wetoxidised wheat straw. Enzyme Microb Technol. 2003; 32(5): 606-15. Publisher Full Text

9. Alvira P, Tomás-Pejó E, Ballesteros MJ, et al.: Pretreatment technologies for an efficient bioethanol production process based on enzymatic hydrolysis: $A$ review. Bioresour Technol. 2010; 101(13): 4851-61. PubMed Abstract | Publisher Full Text

10. Howard RL, Abotsi E, Van Rensburg ELJ, et al.: Lignocellulose biotechnology: Issues of bioconversion and enzyme production. Afr J Biotechnol. 2003; 2(12): 602-619.

Publisher Full Text

11. Chandra RP, Bura R, Mabee WE, et al.: Substrate pretreatment: the key to effective enzymatic hydrolysis of lignocellulosics? Adv Biochem Eng Biotechnol. 2007; 108: 67-93.

PubMed Abstract | Publisher Full Text

12. Mansfield SD, Mooney C, Saddler JN: Substrate and Enzyme Characteristics that Limit Cellulose Hydrolysis. Biotechnol Prog. 1999; 15(5): 804-16. PubMed Abstract | Publisher Full Text

13. Liu H, Zhu JY, Fu SY: Effects of lignin-metal complexation on enzymatic hydrolysis of cellulose. J Agric Food Chem. 2010; 58(12): 7233-8. PubMed Abstract | Publisher Full Text

14. Higuchi T: Lignin Biochemistry: Biosynthesis and Biodegradation. Wood SCI Technol. 1990; 24(1): 23-63. Publisher Full Text

15. Rahman SS, Hossain MM, Choudhury N: Effect of Various Parameters on the Growth and Ethanol Production by Yeasts Isolated from Natural Sources. Bangladesh J Microbiol. 2013; 30(1-2): 49-54. Publisher Full Text

16. Nasir A, Rahman SS, Hossain MM, et al.: Isolation of Saccharomyces Cerevisiae from Pineapple and Orange and Study of Metal's Effectiveness on Ethanol Production. Eur J Microbiol Immunol (Bp). 2017; 7(1): 76-91. PubMed Abstract | Publisher Full Text | Free Full Text

17. Wang J, Hu M, Zhang $\mathrm{H}$, et al: Converting Chemical Oxygen Demand (COD) of Cellulosic Ethanol Fermentation Wastewater into Microbial Lipid by Oleaginous Yeast Trichosporon cutaneum. Appl Biochem Biotechnol. 2017; 182(3): 1121-1130 PubMed Abstract | Publisher Full Text

18. Rahman SS, Sarkar MKI, Islam MR, et al.: Isolation of yeasts from raisins and palm-juice and ethanol production in molasses medium. Indian J Sci Technol.
2016; 9(12) Publisher Full Text

19. Taherzadeh MJ, Karimi K: Process for ethanol from lignocellulosic materials I: Acid-based hydrolysis processes. BioResources. 2007; 2: 472-499. Reference Source

20. Obrink KJ: A modified Conway unit for microdiffusion analysis. Biochem J. 1955; 59(1): 134-6.

PubMed Abstract | Publisher Full Text | Free Full Text

21. Li YJ, Lu YY, Zhang ZJ, et al:: Co-fermentation of Cellulose and Sucrose/Xylose by Engineered Yeasts for Bioethanol Production. Energy \& Fuels. 2017; 31(4): 4061-7.

Publisher Full Text

22. kabashi NA, Alam Z, Ainuddin M: Bio-composting Process Development by SSF for Utilization Agro-industrial Wastes. In: IFMBE Proceedings. 2007; 15: 464-468.

Publisher Full Text

23. Franceschin G, Sudiro M, Ingram T, et al:: Conversion of Rye Straw into Fuel and Xyitol: a Technical and Economical Assessment Based on Experimental Data. Chemical Engineering Research and Design. 2011; 89(6): 631-640. Publisher Full Text

24. Hossain N, Jalil R: Sugar and Bioethanol Production from Oil Palm Trunk (OPT). Asia Pacific Journal of Energy and Environment (APJEE). 2015; 2: 89-92. Reference Source

25. Casa-Villegas M, Marín-Navarro J, Polaina J: Synergies in coupled hydrolysis and fermentation of cellulose using a Trichoderma reesei enzyme preparation and a recombinant Saccharomyces cerevisiae strain. World J Microbiol Biotechnol. 2017; 33(7): 140 . PubMed Abstract | Publisher Full Text

26. Yamada R, Nakashima K, Asai-Nakashima N, et al.: Direct Ethanol Production from Ionic Liquid-Pretreated Lignocellulosic Biomass by Cellulase-Displaying Yeasts. Appl Biochem Biotechnol. 2017; 182(1): 229-37. PubMed Abstract | Publisher Full Text

27. Gnansounou E, Dauriat A: Ethanol Fuel from Biomass: A Review. J Sci Ind Res. 2005; 64: 809-821. Reference Source

28. Velásquez-Arredondo HI, Ruiz-Colorado AA, De Oliveira junior S: Ethanol production process from banana fruit and its lignocellulosic residues: Energy analysis. Energy. 2010; 35(7): 3081-3087. Publisher Full Text

29. Park L, Kim L, Kang K, et al:: Cellulose Ethanol Production from Waste Newsprint by Simultaneous Saccharification and Fermentation using Saccharomyces cerevisiae KNU5377. Process Biochemistry. 2010; 45(4): 487-492. Publisher Full Text 


\section{Open Peer Review}

\section{Current Peer Review Status: $\mathrm{X} X$}

\section{Version 1}

Reviewer Report 30 August 2018

https://doi.org/10.5256/f1000research.15881.r35936

(C) 2018 Khan M. This is an open access peer review report distributed under the terms of the Creative Commons Attribution License, which permits unrestricted use, distribution, and reproduction in any medium, provided the original work is properly cited.

\section{Mohidus Samad Khan}

Department of Chemical Engineering, Bangladesh University of Engineering and Technology (BUET), Dhaka, Bangladesh

The current version of the submitted article doesn't have sufficient content and merit to be indexed as a full journal article. The storyline of the article is not well developed, the relevant references are not well cited, the article doesn't have sufficient results for critical analysis (and how these results are different from other reported results, unless those results are unique and reported for the first time).

It can be included in a conference proceedings (or may not); however, for journal articles we expect high standard research work and publication.

This article reports the production of bioethanol from kitchen waste fermentation.

Not technically sound.

The article does not add any new information to the scientific community.

Very limited results.

No comparison/report on similar work around the world.

This article is not suitable for indexing.

Is the work clearly and accurately presented and does it cite the current literature? No

Is the study design appropriate and is the work technically sound? No

Are sufficient details of methods and analysis provided to allow replication by others? 
Partly

If applicable, is the statistical analysis and its interpretation appropriate? No

Are all the source data underlying the results available to ensure full reproducibility? Partly

Are the conclusions drawn adequately supported by the results?

No

Competing Interests: No competing interests were disclosed.

I confirm that I have read this submission and believe that I have an appropriate level of expertise to state that I do not consider it to be of an acceptable scientific standard, for reasons outlined above.

Reviewer Report 19 June 2018

https://doi.org/10.5256/f1000research.15881.r33555

(C) 2018 Rupani P. This is an open access peer review report distributed under the terms of the Creative Commons Attribution License, which permits unrestricted use, distribution, and reproduction in any medium, provided the original work is properly cited.

\section{Parveen Fatemeh Rupani}

Department of Environment and safety Engineering, Biofuel Institute, Jiangsu University, Ninjing, China

The manuscript has lack of novelty in term of methodology procedure.

The introduction I suggest to focus more on the previous studies of generating ethanol from kitchen waste and show the gap in between. Clear the objective of the study.

The methodology has not been explained well. The process was under anaerobic or aerobic condition? What was the $\mathrm{pH}$ selected for the experiment? No explanation of the pre-treatment of the material, the initial composition characteristics. Also authors did not mention about the size of the sample taken.

Authors have not describe the analytical method used in the study. Full description of the equipment and the methods required.

Authors have to explain in details how many samples were examined, how may runs. And also provide the statistical data in order to discuss the significances of the results.

The results and discussion is very weak and only presented one table. Which is not in scientific 
form. Discussion should be with comparison of the previous studies.

Therefore, I do not recommend for indexing.

Is the work clearly and accurately presented and does it cite the current literature? No

Is the study design appropriate and is the work technically sound?

No

Are sufficient details of methods and analysis provided to allow replication by others? No

If applicable, is the statistical analysis and its interpretation appropriate?

No

Are all the source data underlying the results available to ensure full reproducibility? No

Are the conclusions drawn adequately supported by the results? No

Competing Interests: No competing interests were disclosed.

I confirm that I have read this submission and believe that I have an appropriate level of expertise to state that I do not consider it to be of an acceptable scientific standard, for reasons outlined above.

The benefits of publishing with F1000Research:

- Your article is published within days, with no editorial bias

- You can publish traditional articles, null/negative results, case reports, data notes and more

- The peer review process is transparent and collaborative

- Your article is indexed in PubMed after passing peer review

- Dedicated customer support at every stage

For pre-submission enquiries, contact research@f1000.com

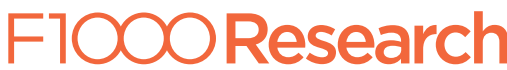

